\title{
MORTALITY AND DIAMETER GROWTH OF LIANAS IN A SEMIDECIDUOUS FOREST FRAGMENT IN SOUTHEASTERN BRAZIL
}

\author{
Julio Antonio Lombardi ${ }^{1}$ \\ Lívia Godinho Temponi ${ }^{1}$ \\ Claudia Aparecida Leite ${ }^{1}$
}

Recebido em 29/12/1998. Aceito em 18/05/1999

\begin{abstract}
Mortality and diameter growth of lianas in a semideciduous forest fragment in Southeastern Brazil). This is a 30-month study of mortality rates and diameter growth rates of lianas in a semideciduous forest fragment in Belo Horizonte, Minas Gerais State, Brazil. Results are presented for 484 specimens of lianas, of which 103 experienced individual mortality ( $21.3 \%$ of the sampled population). Mortality varied according to class of stem diameter, but did not vary throughout the months of year, or between seasons or years. Mortality rates were higher than those recorded in other studies, perhaps due to the age of this secondary forest. Stem diameter growth rates were measured for 385 lianas, the survivors after 30 months plus four plants that died just before the final census, and averaged $1.2 \mathrm{~mm} / \mathrm{year}$, ranging from $0 \mathrm{~mm} /$ year (Chioccoca alba) to $4.8 \mathrm{~mm} /$ year (Acacia $\mathrm{sp}$.), significantly slower than the known growth rates in tropical trees in other areas.
\end{abstract}

Key words - lianas, mortality, diameter growth, Minas Gerais State, secondary forest

RESUMO - (Mortalidade e crescimento em diâmetro de lianas em um fragmento de mata semidecídua no Sudeste do Brasil). É apresentado estudo de 30 meses acerca das taxas de mortalidade e de crescimento em diâmetro de lianas em um fragmento de mata semidecídua em Belo Horizonte, Minas Gerais, Brasil. Os resultados mostraram 484 indivíduos de lianas, dos quais 103 morreram ( $21,3 \%$ da população amostrada). A mortalidade variou com as classes de diâmetro do caule, mas não variou entre os meses do ano, entre as estações do ano, ou entre os anos. As taxas de mortalidade foram mais altas que as observadas em outros estudos, talvez devido à idade da mata secundária. $\mathrm{O}$ crescimento em diâmetro dos caules foi medido para 385 lianas, os sobreviventes ao período de 30 meses, e mais quatro plantas que morreram pouco antes da última medição, e foi em média 1,2 $\mathrm{mm} / \mathrm{ano}$, variando de $0 \mathrm{~mm} / \mathrm{ano}$ (Chiococca alba) a $4,8 \mathrm{~mm} /$ ano (Acacia sp.), significativamente mais lento que as taxas de crescimento em árvores tropicais em outras áreas.

Palavras-chaves - lianas, mortalidade, crescimento em diâmetro, Minas Gerais, mata secundária

\section{Introduction}

Woody climbing plants, or lianas (Gentry 1991), gain access to the canopy by ascending over other species, saving the resources used by trees to make self-supporting trunks. Among angiosperms the climbing habit has evolved many times over; many genera in unrelated families have climbers, and in some families all or most genera have the climbing habit, the case of Aristolochiaceae, Hippocrateaceae, Dioscoreaceae, Smilacaceae, Trigoniaceae and Vitaceae (Gentry 1991).

Although climbers are an important part of diversity in neotropical habitats $(24 \%$ of the total

1 Departamento de Botânica, ICB, Universidade Federal de Minas Gerais, Av. Antônio Carlos, 6627, CEP 31270-110, Belo Horizonte, Minas Gerais, Brasil 
amount of sampled species over $2.5 \mathrm{~cm}$ diam. in dry areas in Ecuador and Mexico, Gentry 1991), this category of plants is underestimated in floristic, phytosociologic and phenological studies (Croat 1975; Ibarra-Manríquez et al. 1991; Molina-Freaner \& Tinoco-Ojanguren 1997; Morellato \& Leitão Filho 1996; Opler et al. 1991; Putz \& Windsor 1987). Studies on other aspects of liana biology are fewer (Putz 1990; 1991; Putz \& Windsor 1987), and no published studies are available on the mortality and growth rates of liana populations in Brazil.

Aiming to contribute to the biological study of lianas in Brazil, in this article we present the results of a 30-month study of mortality and diameter growth of lianas in permanent plots in a fragment of a semideciduous forest in the Belo Horizonte municipality, Minas Gerais State, Brazil.

\section{Material and methods}

The municipality of Belo Horizonte is the most populated portion of Minas Gerais State. A climate, with a dry season from May to September and a rainy season from October to April characterizes the area. The vegetation around Belo Horizonte is a mosaic of fragments of semideciduous forests and rocky grasslands at higher elevations, mixed with urban zones.

Ten permanent $5 \times 50 \mathrm{~m}$ plots (2.5ha) were sampled in parallel lines in the interior of a semideciduous forest fragment located in the Ecological Station of the Federal University of Minas Gerais (EE-UFMG; 1952'40"S, $\left.43^{\circ} 58^{\prime} 20^{\prime \prime} \mathrm{W}\right)$, starting at 5 to $10 \mathrm{~m}$ from the border of the fragment. In 1997 the total monthly rainfall ranged from $428.5 \mathrm{~mm}$ in January, to $0.1 \mathrm{~mm}$ in July and September, the mean monthly temperature ranging from $24.6^{\circ} \mathrm{C}$ in February, to $18.7^{\circ} \mathrm{C}$ in July (data from the Pampulha Airfield Climatologic Station, ca. $1.5 \mathrm{~km}$ from study area). The first census was done in January/1995, and the last in July/1997.

The EE-UFMG is a protected area of ca. 150ha inside the campus of the Federal University of Minas Gerais, and includes several secondary habitats, including herbaceous and shrubby vegetation, swamps, transitional areas of cerrado/ semideciduous forest, and fragments of secondary forest. The sampled area is a forest fragment located on a corner of the EE-UFMG along a highway and a fence, with a ca. $10 \mathrm{~m}$ high canopy, and with some emergent trees of ca. $20 \mathrm{~m}$ high. The edges near the highway are subject to occasional anthropogenic fires, and the exposure to wind, mainly in the dry season, and treefall is common, this not, however, being measured.

All the living lianas in the plots with stem diameters $\geq 0.5 \mathrm{~cm}$ (measured at $70 \mathrm{~cm}$ linear distance from the last rooting point) were sampled. Dense groupings of one species were considered as only one individual, these probably being rooted ramets left, after the fall of the original liana or its canopy support (Putz 1984). Stem diameters were measured at the same point every six months with the use of calipers; only the lianas alive after the 30 -month period of study were counted for diameter growth rate calculations.

The survival of each individual liana was recorded every two months by searching for leaves or reproductive parts in the canopy with binoculars, or by scraping the outer bark of the shoot or branch above the measurement point. Decay of the individual above this point was considered a mortality event (individual mortality), either whether the entire individual had died or only the ramet with its measurement point.

Voucher specimens of fertile lianas were collected, and specimens were deposited in the Herbarium of the Botany Department of the Biological Sciences Institute of the Federal University of Minas Gerais (BHCB).

\section{Results and discussion}

A total of 484 individual lianas were monitored in the 10 plots (193.6/ha), belonging to 18 families and 55 species (Appendix). Thirty five individuals died before collection but were determined to family level; four died at the start of the study before they could be collected and determined.

Mortality - In the 484 marked individuals, 103 experienced individual mortality during the 
study period ( $21.3 \%$ of the sampled population). Mortality occurrences were recorded only to the family level, seeing that a great number of lianas died before proper species determination. Among families with $\mathrm{N}>1$, mortality ranged from 0 to 63.6\% (Asteraceae) (Tab. 1).

Mortality varied with the class of stem diameter $\left(x^{2}=16.96, a=0.05\right)($ Tab. 2$)$, and was greatest among smaller individuals, but did not vary throughout the months of year $\left(x^{2}=6.86, a=\right.$ $0.05)$, or between seasons $\left(x^{2}=0.48, a=0.05\right)$, or years $\left(x^{2}=3.43, a=0.05\right)$ (Tab. 3$)$.

Diameter growth - A total of 385 individuals were evaluated for diameter growth - the survivors after 30 months plus four plants that died just

Table 1. Families of lianas, mortality events, and the percentage of dead individuals in the sampled population after 30 -month study in a fragment of semideciduous forest in Minas Gerais, Brazil ( $N=$ number of individuals at starting of study).

\begin{tabular}{lrrr}
\hline Taxa & $\mathrm{N}$ & Dead individuals & $\begin{array}{c}\text { \% of dead individuals } \\
\text { after 30-month study }\end{array}$ \\
\hline Apoynaceae & 17 & 6 & 35.3 \\
Asteraceae & 11 & 7 & 63.6 \\
Bignoniaceae & 104 & 15 & 14.4 \\
Convolvulaceae & 15 & 7 & 46.7 \\
Dilleneaceae & 59 & 17 & 28.8 \\
Fabaceae & 41 & 7 & 17.1 \\
Hippocrateaceae & 6 & 0 & 0 \\
Loganiaceae & 1 & 0 & 0 \\
Malpighiaceae & 104 & 14 & 13.5 \\
Nyctaginaceae & 1 & 1 & 100 \\
Passifloraceae & 2 & 0 & 0 \\
Polygalaceae & 2 & 0 & 0 \\
Polygonaceae & 29 & 3 & 10.3 \\
Ranunculaceae & 14 & 2 & 14.3 \\
Rubiaceae & 1 & 0 & 0 \\
Sapindaceae & 57 & 15 & 26.3 \\
Sterculiaceae & 13 & 5 & 38.5 \\
Violaceae & 3 & 0 & 0 \\
Undetermined & 4 & 4 & 100 \\
Total & 484 & 103 & 21.3 \\
\hline
\end{tabular}
Table 2. Distribution in diameter class of the sampled lianas in a fragment of semideciduous forest in Minas Gerais, Brazil ( $\mathrm{N}=$
number of individuals at starting of study).

\begin{tabular}{cccc}
\hline $\begin{array}{c}\text { Diameter class } \\
(\mathrm{cm})\end{array}$ & $\mathrm{N}$ & $\begin{array}{c}\text { living after } \\
\text { 30-month }\end{array}$ & $\begin{array}{c}\text { dead } \\
\text { individuals }\end{array}$ \\
\hline $0.5-1.0$ & 153 & 102 & 51 \\
$1.1-2.0$ & 173 & 141 & 32 \\
$2.1-4.0$ & 117 & 101 & 16 \\
$4.1-8.0$ & 32 & 29 & 3 \\
$>8.1$ & 9 & 8 & 1 \\
\hline Total & 484 & 381 & 103 \\
\hline
\end{tabular}

Table 3. Distribution of recorded death events in the lianas along the months, seasons, and years of study in a fragment of semideciduous forest in Minas Gerais, Brazil. Month or season mortality is the sum of mortality events (in 2.5 years) during the corresponding month or season ( $\mathrm{N}=$ number of individuals at starting of study).

\begin{tabular}{|c|c|c|c|c|c|c|c|c|c|c|c|}
\hline & \multicolumn{6}{|c|}{ month } & \multicolumn{2}{|c|}{ season } & \multicolumn{3}{|c|}{ year } \\
\hline & Jan & Mar & May & July & Sept & Nov & Dry & Wet & 1995 & 1996 & 1997 \\
\hline$\underline{\text { Dead lianas }}$ & 25 & 12 & 13 & 21 & 21 & 11 & 48 & 55 & 47 & 32 & 24 \\
\hline
\end{tabular}


Table 4. Stem diameter range, extremes of diameter increase in 30 months, and mean annual secondary growth of lianas in the sampled plots in a fragment of semideciduous forest in Minas Gerais, Brazil ( $\mathrm{N}=$ number of individuals surviving after 30 -month (including four lianas that died just before the final census). $\mathrm{SD}=\mathrm{Standard}$ deviation).

Taxa

\section{Stem diameter range (mm)}

Extremes of
diameter
increase $(\mathrm{mm})$

M. hirsutissima

M. salviaefolia

Bignoniaceae

A. craterophora

A. formosa

A. pulchra

A. samydoides

A. triplinervea

Arrabidaea sp.

Clytostoma sp.

Lundia sp.

M. unguiscati

P. stichadenium

$P$. venusta

S. perforatum

Convolvulaceae

Ipomoea sp.

M. macrocalyx

Dilleniaceae

D. rugosa

D. dentatus

Fabaceae
A. paniculata
Acacia sp.
B. leiopetala
M. brasiliensis
$M$. uncinatum
S. splendida

Hippocrateaceae

$$
\text { H. volubilis }
$$

Loganiaceae

S. brasiliensis

Malpighiaceae

B. adenopoda

B. anisandra

B. argyrophylla

B. oxyclada

B. pubipetala

Banisteriopsis sp.

H. campestris

H. escaloniifolia

M. cordifolia

P. paludosa

Peixotoa sp.

Stygmaphyllon sp.

T. chamaecerasifolia
6-14

$5.5-8$

5-33

18

$7-13.5$

$7-21$

$39-45$

7.5-37

$15-48$

5-47

19-30

23

5-15

7-13

5

5-34

7

6-16

7-27

6-35

7-52

81

39-92.5

40-91

9-56

6-10

$7-65$

6

5-14

$31-78$

7.5-14

$7-136$

5-30

6-25

9-14

$5-37$

5-14

9-47

5-36

6.5

15-17
Mean annual secondary growth

[SD] (mm)
$0-15$

0-9

0

1-4

0.3 [0.8]

1.4 [3.4]

0

3.3 [1.7]

0.8 [0]

0-2

$0.2[0.7]$

0-2

$0.3[0.8]$

$0-8.5$

1.7 [6]

$0-11$

$1.9[4.1]$

2.2 [5.9]

1 [2.4]

2 [0.7]

0.8 [0]

$0.4[0.8]$

0.8 [0.7]

0.4 [0]

0.7 [1.7]

0.4 [0]

2 [3.5]

0-7

0-13.5

0.6 [1.6]

$1.1[3.6]$

3.2 [6.1]

4.8 [0]

2.4 [5.6]

0.8 [2.8]

0.7 [2]

0.5 [1.8]

1.5 [3.4]

0.4 [0]

3.2 [2.8]

1.9 [3.5]

2.1 [2.8]

$1.5[3.4]$

$0-11.5$

1 [2]

0.9 [2.2]

0.4 [0]

0.4 [0.9]

0.9 [1.5]

1.7 [2.9]

$1.6[3.6]$

4.2 [0]

0.4 [1.4] 
Table 4.

\begin{tabular}{|c|c|c|c|c|}
\hline Taxa & $\mathrm{N}$ & $\begin{array}{l}\text { Stem diameter } \\
\text { range }(\mathrm{mm})\end{array}$ & $\begin{array}{c}\text { Extremes of } \\
\text { diameter } \\
\text { increase }(\mathrm{mm})\end{array}$ & $\begin{array}{c}\text { Mean annual } \\
\text { secondary growth } \\
{[\mathrm{SD}](\mathrm{mm})}\end{array}$ \\
\hline \multicolumn{5}{|l|}{ Passifloraceae } \\
\hline $\begin{array}{l}\text { P. galbana } \\
\text { Polygalaceae }\end{array}$ & 2 & $10-12$ & 0 & $0[0]$ \\
\hline B. laurifolia & 2 & $10-44$ & $1-7.5$ & $1.7[4.6]$ \\
\hline \multicolumn{5}{|l|}{ Polygonaceae } \\
\hline Ranunculaceae & 26 & $5-28$ & $0-6$ & $0.9[2]$ \\
\hline $\begin{array}{l}\text { C. dioica } \\
\text { Rubiaceae }\end{array}$ & 12 & $9-27$ & $0-6$ & $1.1[2]$ \\
\hline C. alba & 1 & 12 & 0 & $0[0]$ \\
\hline \multicolumn{5}{|l|}{ Sapindaceae } \\
\hline S. lethalis & 24 & $7-112$ & $0-28$ & $2.8[6.9]$ \\
\hline Serjania sp. 1 & 4 & $6-37$ & $2-7$ & $1.6[2.1]$ \\
\hline Serjania sp. 2 & 8 & $7-120$ & $0-12$ & $1.9[4.4]$ \\
\hline Serjania sp. 3 & 4 & $5-10$ & $0.5-1$ & $0.3[0.2]$ \\
\hline Serjania sp. 4 & 2 & $23-52$ & $2-13$ & $3[7.8]$ \\
\hline \multicolumn{3}{|l|}{ Sterculiaceae } & $0-6$ & 1.2 [1.9] \\
\hline \multicolumn{5}{|l|}{ Violaceae } \\
\hline A. pyrifolia & 3 & $14-31$ & $0-3$ & $0.5[1.5]$ \\
\hline Total & 385 & $0-136$ & $0-28$ & $1.2[3.5]$ \\
\hline
\end{tabular}

before the final census (Tab. 4). The increase in diameter averaged $1.2 \mathrm{~mm} /$ year, ranging from $0 \mathrm{~mm} /$ year (Chioccoca alba, Rubiaceae) to $4.8 \mathrm{~mm} /$ year (Acacia sp., Fabaceae) (Tab. 3).

Understory lianas show little or no diameter growth (Putz 1990), which perhaps accounts for the small growth rates of the sampled lianas in the EE-UFMG, where lianas in the two classes wich smaller diameter are the majority (326 plants or $67.4 \%$ ). This predominance of lianas with small diameter stems is probably due to the disturbance of this secondary vegetation.

The average growth rate of $1.2 \mathrm{~mm} /$ year is, however, similar to the growth rate recorded by Putz (1990) in Barro Colorado Island, Panama, of $1.4 \mathrm{~mm} /$ year, but significantly smaller than the growth rates recorded for tropical forest trees in Barro Colorado $(9.0 \mathrm{~mm} /$ year, Lang \& Knight 1983) and Australia (2.4-4.0mm/year, Herwitz \& Young 1994).

Mortality among lianas of EE-UFMG was higher than that recorded by Putz (1990) for lianas on Barro Colorado (26 individuals in a population of 189 in eight years, or $1.49 \%$ year). In our study site 47 individuals $(9.7 \%$ of the sampled population) died in 1995, 32 in 1996 (7.1\% of the remaining live population of 452 lianas), and 28 during January-July/1997 (5.6\% of the remaining population of 428 plants). The observed higher mortality rate is perhaps due to the stage of regeneration and disturbance frequency of this secondary area subject to periodic fires and a high wind exposure.

\section{Acknowledgments}

The authors thank Dr. C. Jacobi, and anonymous reviewers for suggestions and English language revision. We appreciated the assistance of the botanists that helped identify many specimens: G. Aymard, C. L. Cristóbal, M. S. Ferrucci, A. M. S. da Fonseca Vaz, E. Melo, J. F. Morales, H. Robinson, R. Simão Bianchini, and J. P. Souza. This study was supported by the Conselho Nacional de Desenvolvimento Científico e Tecnológico $(\mathrm{CNPq})$ with a research grant to the first Author, and by undergraduate fellowships to the second and third Authors. 
Appendix. Floristic composition of woody vine species in the sampled plots in a fragment of semideciduous forest in Minas Gerais, Brazil (number of sampled individuals at starting of study).

Apocynaceae

Forsteronia velloziana (A. DC.) Woodson (4)

Prestonia sp. 1 (8)

undetermined (5)

Asteraceae

Dasyphyllum synacanthum (Baker) Cabrera (1)

Mikania hirsutissima DC. (7)

M. salviaefolia Gardner (1)

Mikania sp. (2)

Bignoniaceae

Arrabidaea craterophora Bureau (11)

A. formosa (Bureau) Sandwith (4)

A. pulchra (Cham.) Sandwith (2)

A. samydoides (Cham.) Sandwith (9)

A. triplinervea (DC.) Baill. ex Bureau (7)

Arrabidaea sp. (8)

Clytostoma sp. (2)

Lundia sp. (1)

Macfadyena unguiscati (L.) A. H. Gentry (4)

Pleonotoma cf stichadenium K. Schum. (6)

Pyrostegia venusta (Ker Gawl.) Miers (1)

Stizophyllum perforatum Miers (46)

undetermined (3)

Convolvulaceae

Ipomoea sp. 1 (1)

Merremia macrocalyx (Ruiz \& Pav.) O'Donnell (13)

undetermined (1)

Dilleniaceae

Davilla rugosa Poir. (27)

Doliocarpus dentatus (Aubl.) Standl. (21)

undetermined (11)

Fabaceae

Acacia paniculata Willd. (8)

Acacia sp. (1)

Bauhinia leiopetala Benth. (2)

Machaerium brasiliense Vog. (2)

M. uncinatum (Vell.) Benth. (26)

Senna splendida (Vog.) Irwin \& Barneby (2)

Hippocrateaceae

Hippocratea volubilis L. (6)
Loganiaceae

Strychnos brasiliensis (Spreng.) Mart. (1)

Malpighiaceae

Banisteriopsis adenopoda (A. Juss.) B. Gates (2)

B. anisandra (A. Juss.) B. Gates (3)

B. argyrophylla (A. Juss.) B. Gates (5)

B. oxyclada (A. Juss.) B. Gates (29)

B. pubipetala (A. Juss.) Cuatrec. (10)

Banisteriopsis sp. (6)

Heteropterys campestris A. Juss. (2)

H. escaloniifolia A. Juss. (15)

Mascagnia cordifolia (A. Juss.) Griseb. (4)

Peixotoa paludosa Turcz. (16)

Peixotoa sp. (3)

Stigmaphyllon sp. (1)

Tetrapterys chamaecerasifolia A. Juss. (2)

undetermined (6)

Nyctaginaceae

Bougainvillea spectabilis Willd. (1)

Passifloraceae

Passiflora galbana Mast. (2)

Polygalaceae

Bredemeyera laurifolia Klotzsch (2)

Polygonaceae

Coccoloba scandens Casar. (29)

Ranunculaceae

Clematis dioica L. (14)

Rubiaceae

Chiococca alba (L.) Hitchc. (1)

Sapindaceac

Serjania lethalis A. St.-Hil. (26)

Serjania sp. 1 (5)

Serjania sp. 2 (9)

Serjania sp. 3 (6)

Serjania sp. 4 (2)

undetermined (9)

Sterculiaceae

Byttneria gayana A. St.-Hil. (13)

Violaceae

Anchietea pyrifolia (Mart.) G. Don (3)

Undetermined (4)

\section{References}

Croat, T. B. 1975. Phenological behavior of habit and habitat classes on Barro Colorado Island (Panama Canal Zone). Biotropica 7: 270-277.

Gentry, A.H. 1991. The distribution and evolution of climbing plants. Pp. 3-50. In F. E. Putz \& H. A. Mooney (Eds.), The Biology of Vines. Cambridge University Press, Cambridge.

Herwitz, S. R. \& Young, S. S. 1994. Mortality, recruitment, and growth rates of montane tropical rain forest canopy trees on Mount Bellenden-Ker, Northeast Queensland, Australia. Biotropica 26: 350-361.
Ibarra-Manríquez, G.; Sanchez-Garfias, B. \& GonzalesGarcia, L. 1991. Fenologia de lianas y árboles anemocoros en una selva cálido-húmeda de México. Biotropica 23: 242-254

Lang, G. E. \& Knight, D. H. 1983. Tree growth, mortality recruitment and canopy gap formation during a 10-year period in a tropical moist forest. Ecology 64: 1075-1080.

Molina-Freaner, F. \& Tinoco-Ojanguren, C. 1997. Vines of a desert plant community in Central Sonora, Mexico. Biotropica 29: 46-56.

Morellato, P. C. \& Leitão-Filho, H. F. 1996. Reproductive phenology of climbers in a Southeastern Brazilian forest. Biotropica 28: 180-191. 
Opler, P. A.; Baker, H. G. \& Frankie, G. W. 1991. Seasonality of climbers: a review and example from Costa Rican dry forest. Pp. 377-391. In: F. E. Putz \& H. A. Mooney (Eds.), The Biology of Vines. Cambridge University Press, Cambridge.

Putz, F. E. 1984. The natural history of lianas on Barro Colorado Island, Panama. Ecology 65: 1713-1724.
Putz, F. E. 1990. Liana stem diameter growth and mortality rates on Barro Colorado Island, Panama. Biotropica 22: 103-105.

Putz, F. E. 1991. Silvicultural effects of lianas. Pp. 493-501. In: F. E. Putz \& H. A. Mooney (Eds.), The Biology of Vines. Cambridge University Press, Cambridge.

Putz, F. E. \& Windsor, D. M. 1987. Liana phenology on Barro Colorado Island, Panama. Biotropica 19: 334-341. 